\title{
The Effects of Trait-factor Theory Based Career Counseling Sessions on the Levels of Career Maturity and Indecision of High School Students
}

\author{
Abdullah Atli \\ Department of Counselling and Psychology, Campus, Faculty of Education, Inonu University, Turkey
}

Copyright $\subset 2016$ by authors, all rights reserved. Authors agree that this article remains permanently open access under the terms of the Creative Commons Attribution License 4.0 international License.

\begin{abstract}
The study aimed to research the effect of career counseling sessions based on trait-factor theory on the career maturity and career indecision levels of high school students. 'Single group pretest-posttest test design', one of the weaker test designs, was utilized in the study. The study was conducted with 57 students in Malatya city center high schools in 2014-2015 academic year. 'Career Maturity Scale' and 'Career Decision Scale' were used for data collection in the study. The analysis of the data was conducted using the parametric method, 'related samples t-test' and the non-parametric method, 'Wilcoxon Signed Rank test.' Findings of the study demonstrated that trait-factor theory based career counseling sessions were affective in improving the career maturity levels of the students, while lowering their career indecisiveness.
\end{abstract}

Keywords Trait-factor Theory, Career Counseling, Career Maturity, Career Indecision, High School Student

\section{Introduction}

One of the most important decisions that shape the life of an individual is the decision related to career choice. A healthy career choice might affect the whole of an individual's life. Critical decisions on career choice are made during the years of high school education in Turkey. In that period, high school students concentrated their efforts on their personal traits and occupations. Some high school students are lucky in obtaining correct information on themselves and the professions in the occupational fields they aim to join in the future; however, some others experience serious difficulties in obtaining this information. Informative and guidance requirements of high school students concerning career choice are met by career consulting and psycho-educational groups or group counseling programs and school psychological counselors.
However, in certain schools, there are no school psychological counselors or when they exist, the high number of students in the school restrict the efforts of school counseling service in this field. High school students generally draw upon the school psychological counselors concerning the career choice, to obtain information on their school preferences prior to university entrance exams. Career choice is a long process requiring specialization, which requires the individual to join several activities and receive feedback to define and develop awareness on personal traits and career choice strategies. Unfortunately, most high school students perceive the process of career choice as assistance to accurately organize the professions that pair with their scores they got in the university entrance exams. It is extremely limited and erroneous to simply consider career choice process as correctly associating exam scores with professions in the list of preferences. Yet, during this process, the developmental phases and changes in career progress tasks of the individual should be examined and expert assistance should be provided. Özyürek [33] stated that some individuals in their thirties and forties in Turkey today start the conversation by saying "if only I thought the way I think today' and express that their career choices were as a result of decisions made on necessities. Even today, unfortunately, serious problems continue concerning the necessity to receive professional support in making a career choice.

Career choice is a long-term voyage for the individual, a result of the information and feedback received on the individual's self and professions since childhood [25-36-37]. To be able to make a correct and accurate decision during the selection phase, the individual must be aware of possessed skills, interests and values and obtain professional assistance in how to use these traits. However, it could hardly be argued that this assistance is adequately provided [11-20-47-51].

For the career choice process to proceed in an adequate way, the individual should have some basic skills. The 
concept that reflects this skill is the concept of career maturity. Super [45] defined the concept of career maturity as the ability to make plans about making a career choice, to have awareness about careers, and to assume the responsibility of making a career choice. Brown [11] conceived the career maturity as emotional and cognitive attributes of an individual, which include skills to tackle the situations an individual face when making a career choice. When the definitions on career maturity are evaluated; career maturity could be defined as having knowledge on occupations and the readiness of an individual to make appropriate choices in the light of that knowledge [38-40-43]. An individual should have a certain level of career maturity to make a career choice. It has been conceived that an individual with this competency could make healthier choices. Studies demonstrated that individuals with higher level of career maturity could have healthier career choices [15] and experience lesser career indecision [15-35].

Today, technological and industrial developments have created new lines of business and professions [30]. It has been estimated that there are 12,000 different occupations today. Such a great number of alternatives make it difficult for an individual to make a career choice alone [39]. High number of alternatives in business life and career options helps students to feel career indecision when they could not get the support they need during the critical period in high school, when they need to make a career choice. Career indecision is generally defined as the problem an individual face while making a career choice and during the quest to reach that career [16]. Parsons defined the individuals experiencing career indecision as persons who could not obtain consistent results about their personal traits such as their skills, abilities and interests and their career choices [41]. One of the efficient ways of increasing career maturity and decreasing career indecision of high school students who are in a critical period to make career choices is career counseling. Brown and Brooks [12] defined career counseling as a professional process to help individuals on issues concerning career choices, to resolve their career indecision and to ensure individual-environment harmony.

Career counseling could be seen as a field of expertise in psychological counseling, as well as a field of application of psychological counseling. Many counseling skills that a psychological counselor utilizes during his interactions with his subject could also be used in the process of career counseling. In this respect, career counseling includes a more specific dimension of psychological counseling. However, there are only limited number of studies on the effectiveness of career counseling. This lack of information becomes more clear when the question, which career counseling theory is applied to which counselees, is asked [32]. An efficient career counseling process contributes to hypothetical career planning of the counselee, gathering information on occupations, and using appropriate decision making strategies while making career choices [24]. Career counseling, like other psychological counseling theories, consists of counseling sessions that include different contents and purposes. Career counseling is divided into three phases. These are: the beginning phase, the action phase and the termination phase [32].

One of the efficient theories used in career counseling is the trait-factor theory that Parsons pioneered. Parsons developed the theorem based on the rapid urbanization, immigration, diversification of the business world and the developments in human and behavioral sciences in the United States. Trait-factor theory, being the first career counseling theory, has been used for a long time. Parsons founded the basis of career counseling by stating that the youth, instead of throwing themselves into a field of study just because of luck or because it is easily accessible, should seek advice from experts on occupations and themselves [32]. The basic concepts of the trait-factor theory are "traits" and "factor." According to this theory, the concept of "trait" expresses quantifiable qualities of an individual such as intelligence, attention and ability. The concept of "factor" defines the efficiencies necessary to have a successful career [5]. Parsons argued that an individual should clarify a three-phase process in career choice [44]. These are:

- 1st Phase: Individual's recognition and clarification of own abilities, interests, emotions and boundaries,

- 2nd Phase: Individual's clarification of necessities, conditions, opportunities, advantages and disadvantages of different occupations,

- 3rd Phase: Individual's matching of the information about himself and output that he derived from the information on careers.

To understand Parsons' trait-factor theory better, the three phases of the career choice process could be summarized as below [44]:

1st Phase. Recognition of the individual's self: The beginning phase, which is the initial phase of Parsons' trait-factor theory includes individual's recognition of self-interests, abilities and emotions and gathering of information on the boundaries of these. Trait-factor theory basically aims to identify five traits. These are ability, achievement, interest, value and personality. Determination of the factors of interest and ability, which enable the individuals to learn about themselves and especially make the counselors to recognize these traits and provide guidance accordingly, is significantly important. Thus, the use of the inventories aimed to determine the individual's interests and abilities is essential and one of the vital instruments for the trait-factor theory.

2nd Phase. Gathering information on business world and vocations: Second phase of the trait-factor theory entails career counselor to provide guidance for the subject to find information on vocations and the business world. This phase is also called work/action phase. In this phase, after obtaining information from the individual on vocational choices, the personality traits, abilities, interests and career 
values that match with the individual's target careers are studied. The most significant assistance in this phase is to guide the subject to classify disorganized vocational information and how to access this information. Career counselor could use printed material to provide vocational information. Vocational information catalogues classified based on requirements, educational process, working conditions, working hours, wages, etc. are available both in print and on the Internet. In this phase, it is very helpful to provide a written document to the subject that contains a list of Internet forum addresses for various professionals in different fields.

3rd Phase. Combination of recognition of individual's self and gathering information on business world and vocations: As one of the basic phases of the trait-factor theory, the termination phase contains the matching of the information that the individual recognized about own interests, abilities and career values and the information he gathered on the business world and occupations. For each occupation, different interests, abilities, personality traits and professional values are required. For the individual to make a healthy matching in the final phase, it is necessary for the individual to have completed the initial two phases with success. Career counselor could provide information on trait-factor theory for the subject and could make suggestions. While making suggestions, the abilities, interests, personality traits and career values noticed during the career counseling process should be matched with the qualities of the vocations and their requirements. However, it should also be considered that individual's perception of self traits and the requirements of different vocations have a dynamic structure and they constantly are being changed. Thus, the subject should be informed that the career decision guidance using trait-factor theory could not be a final decision and it could be changed and it could be reconstructed.

Although trait-factor theory is an effective career guidance theorem, it is possible to argue that it also receives criticism today. These are as follows: a] Since trait-factor theory entails the process of matching between the individual and possible careers, it does not meet the requirements of several vocational theories that exert the dynamic structure of career choice [32], b] the fact is that psychological counselor is guiding and authoritarian during the counseling process [5], c] the fact is that the theory limits the counseling process with three sessions and the counseling process seems like only evaluation of test scores [44]. However, despite these criticisms, traits-factor based career psychological counseling is practical for its briefness and efficiency, especially when the numbers of school psychological counselors and the immense number of students at schools are considered.

High school period, an important phase in career choice, is a period when the students require career counseling the most. For several reasons, it could not be argued that psychological counselors working at school guidance services provide this service efficiently. Özyürek and
Kilıç-Atıc1 [34] stated in their study that school psychological counselors could not provide sufficient assistance in career selection process for the students. Another study demonstrated that only $16 \%$ of the students received vocational guidance assistance from the school guidance service [23]. According to Whiston [50], although there are several powerful and efficient career development and career choice theories, there are only limited number of studies in which the efficiency of these theories were tested. It could be observed that the number of studies that could provide sufficient information on the types of effects of career counseling theories on different subjects are still limited. Studies conducted in Turkey on career maturity and career indecision were limited to the determination of career maturity [1-18-22-49-29-42-46] and career indecision [10-23-26] levels of students and comparison based on various variables. In addition to these researches, there are also studies testing the efficiency of group guidance related to career maturity [4-19- 48] and career indecision [6-7-9-27]. A literature review in Turkey revealed no study testing the efficiency of the trait-factor theory based career counseling sessions.

This study aims to determine the efficiency of trait-factor theory based career counseling sessions on career maturity and career indecision levels of high school students. For this purpose, a counseling model designed to guide high school students, who are going through a critical period to make their career choices, in selecting careers suitable to their abilities, interests, career values and personality traits, was tested. Literature review revealed a limited number of international and no local studies in Turkey dealing with the subject matter. Thus, it has been considered that a study in which a career counseling theory was tested empirically and of which findings were presented, would contribute to the literature. It has also been considered that the empirical application process findings of the study would contribute to the school psychological counselors and field researchers alike.

This study will test the following hypotheses:

1. Career maturity level posttest scores of high school students that participate in career counseling sessions conducted using trait-factor theory would increase significantly.

2. Career indecision level posttest scores of high school students that participate in career counseling sessions conducted using trait-factor theory would decrease significantly.

\section{Materials and Methods}

\subsection{Study Design}

This study aims to scrutinize the effects of trait-factor theory, a career counseling theory on career maturity and career indecision levels of high school students. For this purpose, a weak experimental design; "single group 
pretest-posttest design" was utilized. Weak experimental designs are research methods where the researcher works with a single group and intervenes to the group during the experiment. In this design, there is no control group to compare with the test group [21]. Experimental designs are defined as methods where a cause and effect relation could be formed between the independent variables and dependent variables [13]. In line with this design, high school students who applied for psychological counseling were introduced to three personal career counseling sessions. The students selected for test group were initially given career maturity and career indecision scale pretests and after three sessions of career counseling process, posttest was given to determine the efficiency of the counseling sessions. Test group students were not given follow-up tests to determine the permanence of the career counseling applications.

\subsection{Population and Sample}

Samples of the study were high school students attending Malatya province center high schools in the academic year 2014-2015. Psychological counseling candidates [undergraduate junior students] within the context of career counseling applications course preparation, implemented ability, interest, career value and career personality measurement tools on 635 high school students and shared the results with the high school students in their classes under the supervision of the school psychological counselors. High school students who wished to receive personal career counseling were identified during the scale applications and necessary permissions were obtained from the parents of these students by the school directorate and counseling service after providing information on the counseling process. Instead of using career maturity and career indecision scores of the students when determining the test group, the students were asked if they want to participate in the career counseling process and volunteer students were accepted in the test group. A total of 72 psychological counselor candidates executed the career counseling sessions in school guidance services and tape-recorded them, and delivered the career counseling transcripts to the responsible professor for the course. Counseling transcripts were examined by the professor in-charge of the class for certain criteria [trait-factor theory basic principles, three sessions, exact transcription]. As a result of this inspection, counseling sessions by 15 students were excluded from the analysis for not complying to the above-mentioned criteria. Thus, the study was conducted based on the efficiency of career counseling sessions for the counseling sessions executed by 57 students. Psychological counselor candidates implemented the career counseling applications during the month of May 2014. 29 high school students that participated to the study were female [51\%] and 28 were male [49\%]. 7 students [12\%] were 9th grade, 15 [26\%] were 10th grade, 20 [35\%] were 11th grade, and
15 [26\%] were 12th grade students. The average age was 16.77 and the standard deviation was 1.03.

\subsection{Data Collection Tools}

Career Maturity Scale [CMS]: CMS, developed by Crites (1978) to determine the career maturity levels of high school students, was adapted to Turkish by Kuzgun and Bacanl1 [17]. The scale, developed as a five-point Likert rating scale contains 40 items. 19 items out of 40 in the scale reflect wanted attitudes and behaviors related to career maturity [i.e. "I search for resource material to know better about different professions."], while 21 items reflect unwanted attitudes and behaviors [i.e. "I think my elders know which profession is appropriate for me better"]. A high score obtained from the scale shows a high level of career maturity. Cronbach Alfa coefficient of the scale was determined at .89. Besides, a significant relationship was found during validity studies for the scale between the scores the students got in the scale and their university entrance exam scores [39].

Career Decision Scale [CDS]: It was developed by Çakır [17] to determine the career indecision levels of high school students. The scale, developed as a five-point Likert rating scale [not applicable at all to totally applicable to me] contains 30 items. Eight items out of the total 30 measures attitudes towards internal conflicts sub-dimension [i.e. choosing a career is a rather complex, therefore I cannot seem to begin], seven measures attitudes towards insufficient self-knowledge sub-dimension [i.e. I don't know which career is the most appropriate for my personality], seven measures attitudes towards lack of career and field information sub-dimension [i.e. I don't have sufficient information on field and career choices], four measures attitudes towards irrational beliefs related to career choice sub-dimension [i.e. I don't think there is a field or occupation that suits me] and four measures attitudes towards external conflicts sub-dimension [i.e. Certain people that I value the opinion of, do not let me choose the occupation that I want]. A high score obtained from the scale shows a high level of career indecision. Factor analysis was conducted during the structural validity studies for the scale and variance percentage explained by the factors was found as 40.53. Total item correlation coefficients varied between .23 and .57 . Within the context of similar scales validity, to determine the validity of the scale, Career Maturity Inventory, developed by Bacanlı [4] to measure the career maturity levels of high school students, was utilized. It has been assumed that the individuals with career indecision would have lower career maturity levels. The correlation coefficient computed after the implementation was found as $\mathrm{r}=-.68$. Cronbach Alfa coefficient of the scale was determined at .85. Score invariance stability level for the inventory was found using test-retest method. The correlation coefficient for the scale found using test-retest method was found as .83 . 


\subsection{Process}

The study was conducted within the framework of Inonu University Guidance and Psychological Counseling Department spring semester "PDR-352- Career Guidance and Counseling Applications" course. The goals of the Career Guidance and Counseling Applications course were defined as "to develop the knowledge and skills to implement and evaluate measurement tools used in career guidance and career counseling with the individuals and to interpret the profiles of ability, interest and value inventories through personal interviews; to prepare, implement and evaluate the findings of the existing career improvement programs, career group guidance programs or to apply career counseling." In the context of this course, necessary permissions were obtained for PSG undergraduate junior students to conduct career guidance and counseling applications at schools from Malatya Provincial Directorate of National Education in 2014-2015 academic year. Psychological counselor candidates were informed of the tests and inventories [ability, interest, career value, career personality] used in career counseling applications during six weeks within the context of this course. In addition, during this period, since they were short-termed and applicable, counseling examples of trait-factor theory in the literature [3-28-31-44-52] were translated into Turkish and used in training sessions for the psychological counselor candidates and in-class counseling practices were executed. Psychological counseling candidates, after completing their training, commenced the implementations in different high schools. 57 high school students, who wanted to participate in the career counseling application were accepted to join the test group and their sessions were conducted by psychological counselor candidates during the month of May 2014 in the premises of school guidance services. Three personal career counseling sessions were conducted with high school students in the test group, each session lasting for 30-40 minutes. At the end of the semester, psychological counselor candidates presented the exact transcripts of the three sessions they conducted within the framework of trait-factor theory to the professor in-charge. The purpose and the process of trait-factor theory career counseling sessions applied to test group students, together with statements representing the counseling examples, are described below. Statements reflecting the counseling process taken from counseling sessions from different individuals are narrated briefly. Within the career counseling process, the identities are coded as follows: psychological counselor 1 [PC-1], psychological counselor 27 [PC-27], counselee 1 [C-1], and counselee 27 [C-27].

\section{$1^{\text {st }}$ Session}

Purpose: To enable the counselee to recognize his own interests, abilities, career values and personality traits and to distinguish his reflection in daily life.
Process: This counseling session aimed to provide information to the counselee on his personality traits and gain awareness on his reflection on real life. The counselor, by asking questions pertaining to the counselee's participation in activities with pleasure and without feeling boredom aimed to determine the counselee's interests and determine his abilities by asking questions aimed to raise awareness on doing a job nicely and rapidly. Information on the self-opinion of the counselee, personality traits, views about the future, effects of the family on career choice, role models were gathered to form an opinion on the counselee. Standard scales and inventories were utilized for enabling the counselee to learn information about him during the first session. A pre-interview was conducted with the counselees before the counseling sessions and they were informed about the counseling process. During this pre-interview, in order to determine the abilities of the counselee, the abilities section of the "Self-evaluation Inventory" developed by Kuzgun [30] was used; in order to determine the interests of the counselee, "Holland Interests Inventory. During the first session, counselor aimed to explain the scale scores of the counselee using the pre-structured questionnaire. In the course of the counseling session, the similarities and differences between the standard measurement tools scores of the counselee and his responses to the counseling form structured during the counseling were provided as a feedback to the counselee. This process results in the counselee to form realistic perceptions on his own abilities, interests and career values.

Main topics and the questions on the structured questionnaire are presented below:

1. Self-view section [Question examples: Tell me about yourself. What type of person you think you are? What type of person others think you are? What do others think of you? What others say about you?];

2. Strengths and weaknesses section [Question examples: What do you think you can do better than others? What are the things you think you can do better and you experience trouble doing?]

3. Childhood period [Question examples: Your personality as a child, what kind of a child you were? Grumpy, well-behaving, staying wherever he is left, submissive, defiant, shy-timid, hyperactive]

4. Primary school period [Question examples: What do you remember from primary school years about your career choices, abilities, interests, achievements, the competitions you participated, the things your teachers told you are good at, projects, etc.?]

5. Secondary education period [Question examples: What do you remember from high school years about your career choices, abilities, interests, achievements, the competitions you participated, the things your teachers told you are good at, projects, etc.?] 
Counseling transcript samples on the first session are presented below:

Counseling sample 1:

PC-35: What are your strengths? For example the things you think you do better than other people, what would you say if I want you to sort them out?

C-35: I'm not coldblooded. This is a weakness I have. As to my strengths, if I see a fiend wronged about, I cannot stand it, I'd do... I'd tell.

PC-35: You'd not keep silent against wrongdoings and you'd tell what was right. Apart from that trait, what can you say about your other strengths?

C-35: For example I think I'm good at volleyball. I'm successful in Turkish class and I think I'm good at it.

Counseling sample 2:

PC-30: What do you remember from your days in primary school? Things like the profession you'd choose, your abilities, interests or the things your teacher told you are good at, things like that, what do you remember?

C-30: I was such a kid in primary school. Even I don't remember. My mom tells me I was like ambitious. For example I would come back home and cry for hours for why I didn't get 100 and my friend got it. I don't remember until the fifth grade but my mom tells me about it. I'd want to be like that now, too. For example ambitious; in primary school my math grades were like good you know. My teacher used to say I'd become good in positive sciences in the future, he'd say he's so good in math you know. Like that; those were my abilities about primary school, about my childhood, but later on something exactly the opposite happened or I did it with my own hands, I don't know. It's also possible that I could have ended up like that simply because I didn't study. Maybe I'm really good in positive sciences but I myself created these results I think, you know.

PC-30: You say your math was better in primary school as compared to today, but why do you think that change occurred?

C-30: Yes, because I couldn't study, anything else? I was interested in friends and such might have affected it.

\section{2nd Session}

Purpose: Second session includes counselor guiding the counselee to obtain information on occupations and business world.

Process: In the second session, initially the first session was summarized. The second session is generally the phase of action and study. This session aimed to discover the goals of the counselee in depth and to structure an action plan. Within the context of requisites of trait-factor theory, the counselor had prepared the list of occupations based on the high or low scores on the ability, interest, career value and personality tests he implemented. The careers determined were classified according to necessary personal traits, training process, career conditions, working hours, wages, etc. and were shared with the counselee in the counseling session. The information on the introduction and circumstances of occupations were obtained from various web sites, such as Job Placement Agency [İş-Kur] "e-ogrenme.iskur.gov.tr". Also to provide the counselee with in depth information on the occupations he felt close to, Internet addresses that professionals of these occupations contribute to, were shared with the counselee. For instance, the web site on counseling and guidance, the web site "http://www.aktuelrehberlik.com/“was suggested to provide information for the counselee. A document that lists the Internet addresses of forums for different occupations were presented to enable the access of the counselee to these.

Counseling transcript sample on the second session are presented below:

Counseling sample:

PC-20: I have asked you about the occupations you might join in the future. You have told me that you wanted to become a nurse the foremost. There are certain traits that the occupation of nursing requires. It requires to be proficient in courses related to biology, and it is a profession that requires for the candidates to have social assistance interest, because it requires to form empathy with ill people in pain, to understand them and practice health interventions. It is also a profession requiring adapting to irregular shifts since there are turns of duty. Sometimes you might experience tiring and sleepless days. What do you think after hearing these facts, which characteristics of this occupation suit or do not suit you?

C-20: It suits me, shifts and etc., I'll tell you about my childhood, I used to get sick a lot when I was a kid, my father used to take me to the ER all the time. When we were at the emergency room, the nurses there used to take care of me. For that reason, I'd like to stay late for the duty, like day or night, these people need us. I could help them out, yes the night shifts could be tiring. I would get tired, but I wouldn't complain.

PC-20: Nursing is a profession you want. I had given you some tests, and I had shared some with you. In the abilities test I observe that your social abilities are high, social ability entails communicating with people and assisting them. I can say that this skill area is appropriate for nursing and an advantage for you. We see that to interact with people, the social personality, one of the personality traits, is an important personality trait and suitable. Finally I see that on career values, the value of assistance is high as well. We can say that with these results, the occupation of nursing is suitable 


\section{3rd Session}

Purpose: Third session aimed to match the information that the counselee gathered on his interests, abilities and career values with the information he obtained on the business world and occupations.

Process: In the third session, it has been attempted to determine the advance of the counselee in career choice process and to associate the work done in the beginning and action sessions. The counselee has become aware of self-traits, has been informed about certain occupations by the counselor and has been directed to related units for more detailed information. During the last session, an awareness of the counselee to match this information and to clarify appropriate career fields and quests was attempted by the counselor. The counselor encouraged and guided the counselee for the future research on matching counselee's traits and the requirements of occupations process. At the end of the third session, the counseling process was evaluated on the whole and the satisfaction of the counselee's expectations was attempted to be ascertained. Finally, the counselee was informed that the traits and occupations mentioned in the counseling process were not final and career choice is a dynamic process in which personal traits and requirements of occupations rapidly change. After the counseling sessions, the achievements were evaluated by both the counselor and the counselee and imaginary rehearsals were executed concerning the post-counseling processes.

Counseling transcript sample on the second session are presented below:

Counseling sample:

PC-5: You have mentioned certain occupations in our previous sessions. We have talked about them. These were law, career counseling and guidance and marketing. We have talked about these occupations. You have mentioned judicature. We have talked about your need to make research on these occupations and your sources of information.

C-5: Let me start with judicature. I talked with a close friend of my mom, a judge. I said what would happen if I won't decide correctly, how it would happen? Maybe just because he was a judge, he had a harsh reaction. You think wrong. Maybe it has hardships, but it also has advantages. During a verdict, we appoint the laws and regulations as a red line, if you act like that there will be no problems. How can I say it, I initially thought that prosecution and judicature were almost the same, but they were not. I learned that prosecutors gathered information and the judges make decisions.

PC-5: How did the things you heard affect you?

C-5: In fact, I found what I heard logical, but still I'm confused, I wasn't completely convinced.

PC-5: I think you need further information to be able to decide clearly.

\subsection{Data Analysis}

For the analysis of the pretest and posttest scores of the test group, SPSS - Windows 20 program package was used. In the study, the data obtained from the test group was tested for normality hypothesis. To test the normality of the data, histogram graph was scrutinized and the values of kurtosis and skewness were observed to fall between -1 and +1 [14] and displayed in Table 1. For situations where the amount of data is over 50, Kolmogorov-Smirnov Test is proposed for testing against normality hypothesis [13]. Since sample size in the test group was 57, normality hypothesis for the data was tested using Kolmogorov-Smirnov test and presented in Table 1. As could be observed in Table 1, pretest and posttest scores for career maturity met the normality hypothesis requirements, however pretest and posttest scores for career indecision failed to meet the normality hypothesis requirements. Thus, "t-test for correlated samples," a parametric method, was used in the analysis of career maturity pretest and posttest scores, while for the analysis of career indecision pretest and posttest scores, a non-parametric method, "Wilcoxon Signed Rank Test" was utilized [13]. For the analysis of date, significance criterion was accepted to be $\mathrm{p}<.05$.

Table 1. Career Maturity and Career Indecision Scores Kurtosis, Skewness and Kolmogorov-Smirnov Values

\begin{tabular}{|c|c|c|c|c|}
\hline & $\mathrm{n}$ & Skewness & Kurtosis & $\begin{array}{c}\text { Kolmogorov } \\
\text {-Smirnov [sig.] }\end{array}$ \\
\hline $\begin{array}{c}\text { Career Maturity } \\
\text { Pretest }\end{array}$ & 57 & .29 & .20 & .65 \\
\hline $\begin{array}{c}\text { Career Maturity } \\
\text { Posttest }\end{array}$ & 57 & .45 & .31 & .48 \\
\hline $\begin{array}{c}\text { Career } \\
\text { Indecision } \\
\text { Pretest }\end{array}$ & 57 & -1.37 & 2.25 & .00 \\
\hline $\begin{array}{c}\text { Career } \\
\text { Indecision } \\
\text { Posttest }\end{array}$ & 57 & .69 & .18 & .04 \\
\hline \multicolumn{1}{c}{} & & & \\
\hline
\end{tabular}

\section{Findings}

Table 2 demonstrates that there is a significant difference between the career maturity pretest and posttest scores of high school students $[\overline{\mathrm{X}}=32.21, \mathrm{p}<.05]$. The findings show that trait-factor based career counseling application significantly increases the career maturity scores of high school students. Study findings demonstrate that the study hypothesis; "career maturity level posttest scores of high school students that participate in career counseling sessions conducted using trait-factor theory would increase significantly" was verified. 
Table 2. Test Group Students' Career Maturity Pretest and Posttest Related Samples t-test results

\begin{tabular}{|c|c|c|c|c|c|}
\hline & $\mathrm{n}$ & $\overline{\mathrm{X}}$ & $\mathrm{Ss}$ & $\mathrm{t}$ & Sig. \\
\hline $\begin{array}{c}\text { Career Maturity } \\
\text { Pretest }\end{array}$ & 57 & 132 & 23.01 & -11.45 & .00 \\
\hline $\begin{array}{c}\text { Career Maturity } \\
\text { Posttest }\end{array}$ & 57 & 164 & 17.82 & & \\
\hline
\end{tabular}

Table 3 demonstrates that there is a significant difference between the career indecision pretest and posttest scores of high school students $[\mathrm{z}=-6.657, \mathrm{p}<.05]$. The findings show that trait-factor based career counseling application significantly decreases the career indecision scores of high school students. Study findings demonstrate that the study hypothesis; "Career indecision level posttest scores of high school students that participate in career counseling sessions conducted using trait-factor theory would decrease significantly" was verified.

Table 3. Test Group Students' Career Indecision Pretest and Posttest Wilcoxon Signed Rank Test Results

\begin{tabular}{|c|c|c|c|c|}
\hline Posttest/Pretest & $\mathrm{n}$ & $\begin{array}{c}\text { Rank } \\
\text { Average }\end{array}$ & $\begin{array}{c}\text { Rank } \\
\text { Total }\end{array}$ & $\mathrm{Z}$ \\
\hline Negative rank & 57 & 29 & 1653 & $-6.567^{*}$ \\
\hline Positive rank & 0 & .00 & .00 & .000 \\
\hline equals & 0 & & & \\
\hline
\end{tabular}

\section{Discussion, Conclusions and Recommendations}

As a result of the analyses conducted, it has been observed that trait-factor based career counseling sessions significantly increase the career maturity levels of high school students. Career maturity shows that an individual possess sufficient maturity level to make a career choice. Certain counselees, when they do not possess sufficient levels of career maturity, they experience problems in fulfilling their career progress tasks. Obtaining information on their traits and occupations from career counselors in this process would increase counselees' levels of career maturity. Obtaining self-knowledge would decrease the career indecision of an individual and therefore increase the individual's career maturity level [52]. Career counseling process contributes to the counselees' ability to use decision-making strategies and to create awareness on their interests, abilities and values [32]. The findings of the study demonstrate that the career maturity levels of the high school students, who received career counseling, have increased and their career indecision levels have decreased due to the fact that they have obtained information on themselves and occupations and the increase in their levels of awareness. Findings of the study demonstrate that trait-factor theory based career counseling sessions had positive effects on the levels of career maturity of high school students. Empirical studies on group counseling about career maturity show similarities with the findings of this study and shows that it is affective in raising the career maturity levels of the students. In a study that Bacanli [4] conducted with high school freshmen, it has been noted that career group counseling activities were affective in increasing the students' career maturity levels. As a result of a study by Uskaner [48] based on pretest-posttest model, it has been conceived that the career maturity levels of the students in test group were higher than the career maturity levels of the students in the control group. İşgör and Sezer [2008], in a study with freshmen and sophomore high school students, determined that an eight weeks long in-class career counseling activity aimed to increase students' career maturity levels increased the career maturity points of the students. Likewise, Evren [19] obtained results confirming that the students who received career group counseling application had significantly higher career maturity levels as compared to the control group in a study with 8th grade students using a pretest-posttest test and control group model.

Another finding of the study is that, trait-factor based career counseling sessions significantly decrease the career indecision levels of high school students. It has been emphasized that a counselor will be effective as a result of a counseling process, in which an effective career consultant would structure the individual's life experiences and integrate these with the career roles. To be able to arrive at this efficiency, formal and informal evaluation methods and techniques could be utilized [5]. In the study, during the first session process of the counseling process, life experiences of students were put on the agenda and the analogy between the data acquired with the standard measurement tools and the counselee's real-life experiences were attempted to be explained to the counselee. This process was effective in reducing the possible indecision the students experience in making career choices. Empirical studies on group counseling about career indecision show similarities with the findings of this study and shows that it is affective in decreasing the career indecision levels of the students. Bozgeyikli [9] in a group counseling program he designed using trait-factor and cognitive behaviorist approaches, implemented with eighth grade students, aimed to improve the self-efficacy levels of eighth grade students in career decisiveness. After the study, it has been demonstrated that the program was effective in improving self-efficacy levels in career decision-making of eighth grade students. Bilgin [7] showed that the career decisiveness levels of the students in test group increased in an empirical study conducted by using a group experience to provide high school students who experience career indecision, an introduction to interests and values, and information about occupations. Egner and Jackson [1978] in a study that investigated the effects of group psychological counseling response program on career decisiveness skills, created an experimental program that aimed to develop career maturity levels and decision-making skills of high school students. The 
program, which included individual and group activities, consisted of 15 parts and was presented by the counselor to the students during 10 weeks in the classroom. The results of the program showed that decision-making skills of the participating students have improved [17].

When it is considered that the individuals with higher career maturity levels have more information on career progress tasks, it has been expected these individuals to have lower career indecision levels. Thus, individuals with higher career maturity levels, utilize logical decision-making strategies among the decision-making strategies. Blustein [8] in a study conducted with college students, has been stated that students who decide using logic in their decisions would have higher career maturity levels, thus having better decision-making skills on career choice. In a study by Akıntuğ and Birol [2], which scrutinized the relation between the career maturity levels and decision-making strategies of high school students, it has been shown that the students with high levels of career maturity received higher scores in logical decision-making strategies sub-dimension.

In the present study, the effect of psychological career counseling sessions conducted using trait-factor theory on career maturity and career indecision levels of high school students. Study results demonstrated that career maturities of students who received trait-factor theory based psychological career counseling increased and their career indecision levels decreased. In other words, it could be argued that the conducted empirical study increased self-awareness of high school students who are at a critical juncture in making a career decision and their knowledge on self-abilities and career values.

\section{Limitations and Recommendations}

As with any study, the present research has limitations as well. The lack of a control group in addition to the test group in the study could be considered as a limitation in testing the effectiveness of the applied counseling program. Another limitation is the lack of the application of a monitoring test to test the retention of the effect of the implemented counseling sessions. These facts prevent the assessment of long-term results of the present study. It is considered that future studies should consider these limitations in the methodology.

As a result, it has been observed that trait-factor theory based career counseling sessions are effective in improving career maturity levels and in decreasing the career indecision levels of high school students.

It should be noted that there were certain limitations in the study concerning the planning and application of the experimental process. These limitations are stated below:

a) The fact that no control or comparison group was formed in addition to the test group in the study is considered as a limitation in testing the efficiency of the counseling program implemented. b) The fact that no follow-up test was implemented to test the permanency of the effects of the counseling sessions applied to the test group is considered as a limitation.

c) The counseling transcripts of the counselor candidates were only evaluated by the researcher [supervisor] and inspected for compliance with trait-factor theory. Inspection of counseling sessions by another expert would increase the reliability of the study. The lack of this secondary control by another field expert is considered as a limitation for the study.

d) In the light of the findings of the study, following propositions could be argued for further studies on career counseling and guidance:

e) No control group was formed in addition to the test group in this study. Further completely empirical studies could test the efficiency of trait-facto theory based career counseling sessions.

f) This study worked on career maturity and career indecision. Future studies could study the efficiency of trait-facto theory based career counseling sessions using other variables.

g) This study was conducted with high school students. Future studies could be especially conducted with junior high $8^{\text {th }}$ grade students to test the efficiency of the program.

h) The career counseling model should be explained to the psychological counselors working at school guidance services using in service training.

i) This study utilized trait-factor theory based career counseling applications were utilized because of their brief character. Studies where the efficiency of career counseling applications were scrutinized are limited both internationally and in Turkey. Thus, it would be extremely meaningful to test the efficiency of different career counseling theories on similar groups and to compare their efficiencies.

j) The study demonstrated that one career counseling model was effective on career maturity and career indecision levels of high school students. It is our opinion that, in the syllabus of the courses in Guidance and Psychological Counseling undergraduate programs that cover career guidance and counseling, instead of concentrating on information on scales and their applications, should give more emphasis to career counseling applications.

\section{REFERENCES}

[1] Akbalık, G. (1991). Professional maturity level of junior high school students (Unpublished master's thesis). Ankara University, Institute of Educational Sciences, Ankara. 
[2] Akıntuğ, Y., \& Birol, C. (2011). Comparative analysis of vocatioanl maturity and decision making strategies of high school students. H.U. Journal of Education, 41, 1-12.

[3] Ali, L., \& Graham, B. (2001). The counselling approach to careers guidance. ABD: Taylor \& Francis Group.

[4] Bacanl1, F. (1995). The effect of vocational maturity level group of high school students of vocational guidance (Unpublished master's thesis). Gazi University, Institute of Social Sciences, Ankara.

[5] Bacanlı, F. (2011). Özellik-faktör uyumlu kuramlar. In B.Yeşilyaprak (Ed.), Mesleki rehberlik ve kariyer danışmanlı̆̆ kuramdan uygulamaya [Vocational guidance and career counseling from theory to practice ] (89-126). Ankara: Pegem Akademi.

[6] Bal, P. N. (1998). The Study of career maturity and the effectiveness of career decision making program on high school adolescents (Unpublished doctoral thesis). Marmara University, Institute of Educational Sciences, İstanbul.

[7] Bilgin, A. (1995). Group counseling high school students to influence the behavior of independent professional judgment to give their parents (Unpublished doctoral thesis). Ankara University, Institute of Educational Sciences, Ankara.

[8] Blustein, D.J. (1987). Decision-making style and vocational maturity: An alternative perspective. Journal of Vocational Behavior, 30, (1), 61-71.

[9] Bozgeyikli, H. (2004). Developing a scale measure career decision making selfefficacy. Selçuk University Journal of Social Sicience, 11, 221-234.

[10] Bozkurt, P. (2005). The examination of difficullty level of professional decision making of 11th grade students in high schools according to parents attitudes and some nature characteristics (Unpublished master's thesis). Selçuk University, Institute of Social Sciences, Konya.

[11] Brown, D. (2003). Career information, career counseling and career development. ABD: Pearson Education, Inc.

[12] Brown, D., \& Brooks, L. (1990). Career Counseling techniques. Allyn \& Bacon.

[13] Büyüköztürk, Ş., Kılıç-Çakmak, E., Akgün, Ö.E., Karadeniz, Ş., \& Demirel, F. (2010). Bilimsel araştırma yöntemleri [Research Methods]. Ankara: Pegem Akademi.

[14] Can, A. (2013). SPSS ile bilimsel araştırma sürecinde nicel veri analizi [Quantitative data analysis in the scientific research process with SPSS]. Ankara: Pegem Akademi.

[15] Creed, P. A., \& Patton, W. (2002). Predicting two components of career maturity in school based adolescents. Journal of Career Development, 29 (4), 277-290.

[16] Crites, J.O. (1969). Vocational psychology: The study of vocational behavior and development. New York: Mc Graw-Hill.

[17] Çakır, M.A. (2013). The Effect of a career group guidance program on the career indecision level of high school students (Unpublished doctoral thesis). Ankara University, Institute of Educational Sciences, Ankara.

[18] Çoban, A. E. (2005). investigation of the vocational maturity levels of 11 th grade students in relation to some predictive variables. Journal of Education Faculty, 6 (10), 39-54.
[19] Evren, M. (1999). The Effect of vocational group guidance on vocational maturity, vocational self-concept and vocational preferance of the 8 th grade students whose genders are different in the school of basic education (Unpublished master's thesis). Hacettepe University, Institute of Educational Sciences, Ankara.

[20] Foley, P. F., Kelly, M. E., \& Hartman, B. W. (2006). Career indecision. In J.H. Greenhause \& G.A. Callanan (Eds.), Encyclopedia of career development (109-115). London: Sage Publications.

[21] Fraenkel, J. R., Wallen, N. E., \& Hyun, H. H. (2012). How to design and evaluate research in education (8th edition).New York: McGraw Hill.

[22] Gülbahçe, A. (2007). An analysis of self image and social comparison of the students who have different career maturity levels (Unpublished doctoral thesis). Atatürk University, Institute of Educational Sciences, Erzurum.

[23] Hamamc1, Z., \& Hamurlu, K. (2005). Relationshıp between level of knowledge and attitudes of parents about helping their children for career development and career indecision of their children. Inonu University Journal of the Faculty of Education, 10, 55-69.

[24] Holland, J. L., Magoon, T.M., \& Spokane, A. R. (1981). Counseling psychology: Career interventions, research, and theory. Annual Review of Psychology, 32, 279-305. DOI: 10.1146/annurev.ps.32.020181.001431.

[25] Inkson, K., \& Elkin, G. (2008). Landscape with travellers: The context of careers in developed nations. In. J. A. Athanasou \& R.V. Esbroeck (Eds.), International Handbook of Career Guidance. Springer Science+Business Media.

[26] Kesici, Ş. (2007). Parental attitudes and guidance career decision making difficulties of high school students. Selçuk University Journal of Social Science, (18), 329-340.

[27] Kirdök, O. (2010). An evaluation of the career decision making program based on cognitive information processing approach (Unpublished master's thesis). Çukurova University, Institute of Social Sciences, Adana.

[28] Kidd, J. M. (2006). Understanding career counselling: Theory, research and practice. London: SAGE Publications Ltd.

[29] Kök, M. (2013). Investigation about relation between cildhood traumatic experiences and vocational maturity level of high school last grade students (Unpublished master's thesis). Atatürk University, Institute of Educational Sciences, Erzurum.

[30] Kuzgun, Y. (2000). Meslek danışmanlı̆̆ kuram ve uygulamalar [Career counseling theories and practices]. Ankara Nobel Yayın Dağıtım.

[31] Nathan, R., \& Hill, L. (2006). Career counseling. London: Sage Publications.

[32] Niles, S. G., \& Harris-Bowlsbey, J. (2013). Career development interventions in the 21st Century (4th Edition). Pearson

[33] Özyürek, R. (2013). Kariyer psikolojik danışmanlı̆̆̆ kuramlart: Çocuk ve ergenler için kariyer rehberliği uygulamalarl [Career counseling theories: career guidance programs for children and adolescents]. Ankara: Nobel Akademi 
[34] Özyürek, R., \& Kılıç-Atıcı, M. (2002). Determining sources which are effetive in university students' career decision making. Turkish Psychological Counseling and Guidance Journal, 17, 33-42.

[35] Patton, W., \& Creed, P. (2007). The relationship between career variables and occupational aspirations and expectations for Australian high school adolescents. Journal of Career Development, 34, 127-148.

[36] Patton, W., \& Mcmahon, M. (2006).Career develpment and system theory. Netherland: Sense Publishers.

[37] Perry, N., \& Vanzandt, Z. (2006). Exploring future options, a career development curriculum for middle school student. New York: Ideabate press books.

[38] Powell, D. F., \& Luzzo, D. A. (1998). Evaluating factors associated with the career maturity of high school students. The Career Development Quarterly, 47,145-158.

[39] Reeves, D. L., \& Karlitz, G. (2005). Career ideas for teen education and training. New York: Bright Futures Press.

[40] Savickas, M. L. (1984). Career maturity: The construct and its measurement. Vocational Guidance Quarterly, 32 (4), $222-231$.

[41] Savickas, M. L. (1995). Constructivist counseling for career indecision. Career Development Quarterly, 43,4, 363-374.

[42] Sekmenli, T. (2000). School examined in terms of some variables of trait anxiety levels of students of vocational maturity (Unpublished master's thesis). İnönü University, Institute of Social Sciences, Malatya.

[43] Seligman, L. (1980). Assessment in developmental career counseling. Cranston: Carroll Press.
[44] Sharf, R. S. (2006). Applying career develpment theory to counseling. USA: Thomson Brooks/Cole.

[45] Super, D. E. (1977). Vocational maturity in mid-career. Vocational Guidance Quarterly, 25 (4), 294-302.

[46] Sahin, K. (2010). Examination of the relationship between occupational maturity level and decision making strategies of secondary school students (Unpublished master's thesis). Maltepe University, Institute of Social Sciences, İstanbul.

[47] Taber, B.J., Hatung,P. J., Briddick, H., Briddick,W.C., \& Rehfuss, M. C. (2011). Career style 1nterview: A contextualized approach to career counseling. The Career Development Quarterly, 59, 274-287.

[48] Uskaner, A. (1999). The Effects of the vocational group guidance over the vocational maturity level of high school fresmen (Unpublished master's thesis). Çukurova University, Institute of Social Sciences, Adana.

[49] Ürün, E.A. (2010). The relationship between the self-esteem level and the vocational maturity of high school students (Unpublished master's thesis). Balıkesir University, Institute of ESocial Sciences, Balıkesir.

[50] Whiston, S.C. (2003). Career counseling: 90 years old yet still healthy and vital. The Career Development Quarterly, 52, $35-42$.

[51] Yeşilyaprak, B. (2012).The Paradigm shift of vocational guidance and career counseling and its implications for Turkey: An evaluation from past to future. Educational Sciences: Theory \& Practice, 12 (1), 97-118.

[52] Zunker, V. G. (2006). Career caunseling a holistic approach. ABD: Brooks/cole product. 